\title{
A cross-cultural evaluation of the psychometric properties of Information Seeking Anxiety Scale in Pakistani environment
}

\author{
Muhammad Asif Naveed ${ }^{1,2}$ and Kanwal Ameen ${ }^{1}$ \\ ${ }^{1}$ Department of Information Management, \\ University of the Punjab, Lahore, PAKISTAN \\ ${ }^{2}$ School of Governance and Society, \\ University of Management and Technology, Lahore, PAKISTAN \\ e-mail: masifnaveed@yahoo.com; kanwal.im@pu.edu.pk (corresponding author);
}

\begin{abstract}
This study investigated the psychometric properties of Information Seeking Anxiety Scale (ISAS) using postgraduate students in a Pakistani university. A 47-item ISAS was administered to 297 students, selected through stratified convenient sampling procedure, by visiting each department at the university. An eighty-five percent response rate was achieved through usable returned questionnaires. The principal component analysis (PCA) using varimax rotation yielded six-factor solution to the Information Seeking Anxiety Scale (ISAS), namely, (1) Resource Anxiety; (2) ICT Anxiety; (3) Library Anxiety; (4) Search Anxiety; (5) Mechanical Anxiety; and, (6) Thematic Anxiety. This six factors corresponded to those of Erfanmanesh, Abrizah, and Karim (2012) but differed somewhat with regard to the statements loaded on each factor. Moreover, these six-factors combined together accounted for 52.7 percent of the total variance explained. Seven item were dropped as a result of reliability analysis resulting 40-item instrument. Also, the values of Cronbach's internal reliability coefficient alpha for overall ISAS and its sub-scales were found satisfactory as recommended by Nunnally and Bernstein (1994). These results demonstrated the psychometric soundness and stability of ISAS when tested with Pakistani postgraduate students recruited from a research-intensive university. More psychometric studies are required before drawing any sound conclusions regarding adequacy of ISAS in assessing information seeking anxiety in Pakistani information users.
\end{abstract}

Keywords: Information Seeking Anxiety; Information behaviour; ISAS; Psychometric analysis; Postgraduate students.

\section{INTRODUCTION}

Anxiety in information seeking process has been the subject of many empirical investigations by information professionals working in university libraries since mid-1980s. Several researchers had touched this area in one way or the other. It was, therefore, the proposed area had gone through many changes and different tags were used for its representation. Swope and Katzer (1972) identified the reasons for non-question-asking behavior of library users who seemed anxious, confused and frustrated. The major reason for avoiding help from the library staff was due the dissatisfaction with prior library service. This conception was labeled as 'people problem'. The study of Hatchard and Toy (1986)

https://dx.doi.org/10.22452/mjlis.vol22no3.3

Page | 35 
discovered that students did experience emotional problems while approaching library staff for help. Moreover, they recommended the need for investigations examining determinants of users' decision for approaching the librarian. It was Mellon (1986) who developed library anxiety theory grounded in the understanding of university students from freshman English courses. She discovered the way these students become anxious in searching for information at library. In addition, she explored that they were stymied in library search by feelings of anxiety or fear and "unable to approach the problem logically or effectively" (p.163). A few years later, Kuhlthau (1988; 1991) also observed anxiety as a cardinal, omnipresent, and persistent characteristic of information search process (ISP).

\section{LITERATURE REVIEW ON MEASURING INFORMATION ANXIETY}

Bostick (1992) conceptualized it as a multi-dimensional construct and developed a psychometric scale for undergraduates known as LAS (Library Anxiety Scale) in order to measure users' anxiety while looking for information in a conventional library setting. She started with a master list of 294 statements, developed based on experts' advice, which was administered in two phases in undergraduates. By applying a variety of statistical measures, a 43-item instrument was developed. These 43-items were grouped into five sub-dimensions: (1) staff barriers, $\alpha=0.90$; (2) affective barriers, $\alpha=0.80$; (3) comfort with the library, $\alpha=0.66$; (4) barriers with library knowledge, $\alpha=0.62$; and (5) mechanical barriers, $\alpha=0.60$. LAS was reported a valid and reliable instrument to measure library anxiety because it indicated an adequate internal consistency $(\alpha=0.80)$. Bostick's LAS, since its development in 1992, has been utilized extensively due to cultural and local reasons to assess library anxiety construct among undergraduate students across different library environments (Jiao and Onwuegbuzie 1997, 1998, 1999, 2001; Jiao, Onwuegbuzie, and Lichtenstein 1996; Onwuegbuzie 1997; Onwuegbuzie and Jiao 1997, 2000; Karim and Ansari 2010). It had a few modifications and translations owing to different educational, cultural, geographical grounds (Anwar, Al-Kandari and Al-Qallaf 2004; Swigon 2011; Shoham and Mizrachi 2004; Van Kampen 2004). Anwar, Al-Kandari and Al-Qallaf (2004) stated that original LAS was superannuated and it needs to be adapted to the contemporary information space.

Van Kampen (2004) were of the view that "When the LAS was developed, scant information and few theories were available on the user's feelings during the research process itself; the Internet was not yet widely used as a research tool, and database access was limited primarily to the physical confines of the library" (p. 29). She developed, based on Bostick's Library Anxiety Scale, and validated a 54-item Likert-type instrument and named it as Multidimensional Library Anxiety Scale (MLAS). The data were collected in two phases by surveying 299 doctoral students. The construct validity and internal reliability of the scale was established using factor analysis and a test-retest respectively. MLAS had six components: (1) comfort and confidence when using the library, $\alpha=0.86$, (2) information seeking process anxiety, $\alpha=0.87$ ), (3) staff barriers, $\alpha=0.73$, (4) perceived importance of the library, $\alpha=0.79$, (5) library technologies competence, $\alpha=0.73$, and comfort level while inside the library building, $\alpha=0.74$. These components explained 43.39 percent of the total variance. The MLAS had satisfactory internal consistency $(\alpha=0.88)$ to measure library anxiety among doctoral students. Moreover, the results indicated that doctoral students experienced anxiety in information search process at library that increased to the highest level in the first (Task Initiation) and the third stage (formulation) of Kuhlthau's ISP Model (Kuhlthau 1988, 1991). MLAS has been used by a few studies since its development (Erfanmanesh 2011; Platt and Platt 2013). 
Considering the age and unsuitability of Bostick's LAS in drastically changed library environment, Anwar et al. (2012) developed and validated AQAK to measure library anxiety in undergraduates. First of all, a list of 1512 items were prepared. Afterward, these items were scrutinized by researchers for duplication and merger of closely related items resulting a master list of 212 statements. These items were again closely scrutinized for further refinement which resulted a draft-instrument containing a list of 137 items that was submitted to five experts for review (p. 40). As a result of expert review and revision by the researchers, 57 more items were excluded. The remaining 80 items, each with a 5 point Likert scale, formed the first data collection instrument. The pilot instrument, containing 80 statements each with a 5-point Likert scale, was administered three stages using undergraduates from Kuwait University. The statistical analysis resulted 40-item AQAK with five factors, namely, Information resources ( 6 items, $\alpha=0.723$ ); Library staff (10 items, $\alpha=0.843$ ); User knowledge (12 items, $\alpha=0.772$ ); Library environment ( 7 items, $\alpha=$ 0.758 ); and User education ( 5 items, $\alpha=0.625$ ). The AQAK was reported as a highly reliable and valid library anxiety measure as it indicated $90 \%$ internal reliability.

The previous studies investigated users' anxiety regarding information seeking tasks in a conventional information space known as library. The advent and proliferation of ICTs and WWW have drastically changed the conventional information environment in the present era as the library has become a warehouse of information resources which can be accessed remotely from anywhere. Although library anxiety is still one of the dimensions affecting users' information seeking in the digital era, the library is only a setting now where students sought information for academic needs. Considering the present information environment, there was a need to expand the concept of information seeking anxiety while using a variety of information resources, including the library, web and human. Realizing the present information landscape, Erfanmanesh, Abrizah and Karim (2012) designed a study for development and validation of Information Seeking Anxiety Scale (ISAS) for postgraduate students. The research team began with a master list of 93 items which was developed using existing research, experts' advice, and interviews of some postgraduates. The pilot instrument was administered on postgraduates at a Malaysian research-intensive university in two phases. The data processing using a variety of statistical measures resulted a 47 -item Likert type instrument. These 47 items were clustered into six factors, namely, barriers with information resources (14 items, $\alpha=0.868$ ), computer and internet barriers ( 10 items, $\alpha=0.726$ ), barriers associated with library (11 items, $\alpha=0.815$ ), barriers with searching for information (7 items, $\alpha=0.802$ ), technical barriers (7 items, $\alpha=0.809$ ), and topic identification barriers ( 5 items, $\alpha=0.825$ ). These factors collectively explained about $35 \%$ of the total variation in information seeking anxiety construct. The resulting instrument had a satisfactory internal reliability as the value of alpha coefficient $(\alpha=0.902)$ for overall scale was very high. Subsequently, the prevalence and levels of information seeking anxiety construct using Information Seeking Anxiety Scale was examined. The results indicated that a large majority of post-graduate students had experienced different levels (low, mild, moderate, and severe) of information seeking anxiety (Erfanmanesh, Abrizah and Karim 2014a, 2014b; Naveed and Ameen 2016). Search avoidance, task avoidance, and research avoidance behaviours were reported as an outcome of negative effects of information seeking anxiety (Naveed 2016).

Erfanmanesh, Abrizah and Karim (2012) suggested that newly developed scale (ISAS) needs to be examined further to determine the extent of construct validity and reliability using students from different educational, cultural and geographical backgrounds. It was legitimate to raise the question whether students having different origins and contexts would share the same type of information seeking anxiety as do the Malaysian students. There was a need for cross-cultural evaluation of ISAS so that the validity and reliability of 
ISAS might be tested. A perusal of published research resulted that no study appeared to have been conducted so far using ISAS on a culturally and geographically different population, such as Pakistan.

\section{OBJECTIVE AND METHOD}

The current study was, therefore, designed to investigate the psychometric properties of ISAS while employing it on postgraduate students of University of the Punjab, Lahore. This study was geared towards answering the following research questions:

(a) Would ISAS be able to measure information seeking anxiety among postgraduate students in a Pakistani environment?

(b) Would ISAS be able to establish construct validity and internal reliability when tested with a culturally different postgraduate students from Pakistan?

\section{Population and Sample}

The targeted population for the proposed research was all the postgraduate students enrolled in M. Phil and PhD programs at a university in Punjab, Lahore. This university was purposively selected as a study setting because it is the largest, oldest and a researchintensive university of Pakistan. There were about thirteen hundred (1300) postgraduate students enrolled in the Faculty of Science, Faculty of Economics \& Management Science, and Faculty of Behavioural and Social Science. The sample size consisted of 297 postgraduate students which was determined by using 95 percent confidence level and five percent margin of error. These students were selected using convenient sampling technique because the selection of participants using simple random or stratified random sampling was not possible due to the time limitation and accessibility issues. Although the population was listed and identifiable, their availability via random selection was not possible due to the non-availability of lists along with their contacts. Furthermore, because most of these students, especially those who have completed their course work and are working on their synopsis and thesis, visit their departments by appointment with their supervisors. It was, therefore, decided to use convenient sampling technique for participants' selection.

\section{Instrumentation and Data Collection}

This study utilized a questionnaire survey containing Information Seeking Anxiety Scale (ISAS) developed and validated by Erfanmanesh, Abrizah, and Karim (2012). The researchers included all the 47-items in data collection instrument. The survey instrument with a covering letter was administered personally to the participants using social contacts of the researcher by visiting each department with written permission from departmental head and consent of the respondents for participation in survey. The lecturers and the librarian of each department played a very important role in data collection from the students. All the respondents were supposed to record their responses on 5-point Likert scale ranging from strongly disagree (1) to strongly agree (5) against each item. The researcher received a total of 262 filled questionnaires indicating the $88 \%$ response rate which is highly acceptable. These returned questionnaires were checked and reviewed for accuracy and completeness of information. Of the 262 questionnaires, 251 provided complete and accurate data for the entire survey instrument whereas 11 were found with incomplete and insufficient information. These questionnaires were, therefore, eliminated and the data from the remaining 251 (84.5\%) were analyzed. Prior to data analysis, the data from received questionnaires were coded and entered into IBM SPSS (Statistical 
Products Services and Solution). After data entry, the negatively worded items were reversed so that all the items might be scored in the same direction. Then, data were analyzed by applying a variety of statistical techniques.

\section{Data Analysis}

This study utilized the exploratory factor analysis for identification of appropriate number of factors and statements grouping in identified factors because it was most commonly used measure for reducing a large number of responses or questions into a few more meaningful groupings (Tabachnick and Fidell 2007; Gay, Mills, and Airasian 2009). Prior to factor analysis, the sampling adequacy was examined using the Kaiser-Meyer-Olkin measure of sampling adequacy. Moreover, Bartlett's test of sphericity was used to test the presence of correlation among variables (item or statements). Cronbach's Internal Reliability Coefficient Alpha was used to determine the internal consistency of the overall ISAS and its sub-dimensions because it is an accepted and most commonly used measure of internal consistency and reliability (Gliner and Morgan 2000; Erfanmanesh, Abrizah and Karim 2012). Moreover, this measure had successfully been used to estimate the internal consistency and reliability by many researchers (Anwar, Al-Kandari, and Al-Qallaf 2004; Anwar et al. 2012; Bowers 2010; Erfanmanesh, Abrizah and Karim 2012).

\section{ANALYSIS OF DATA AND RESULTS}

\section{Construct Validation using Exploratory Factor Analysis}

We need to examine sampling adequacy and presence of correlation among variables (statements or items) for factor analysis to work. Kaiser-Meyer-Olkin (KMO) measure of sampling adequacy and Bartlett's test of sphericity were used to ensure appropriateness of data for factor analysis. According to Tabachnick and Fidell (2007), both these tests examine correlations among variables (items or statements) to indicate whether factor analysis is appropriate. Table 1 displays the results of these two tests. The KMO measure of sampling adequacy yielded a value of 0.848 which was close to 1.0, i.e. great and acceptable (Kaiser 1981; Hutcheson and Sofroniou 1999; Tabachnick and Fidell 2007; Field 2009) and suggested the sampling adequacy for running factor analysis.

Moreover, we require adequate common or homogeneous variance (correlation) between the variables (statements or items) in the collected data set to proceed with exploratory factor analysis. The Bartlett's test of sphericity was significant (chi-square $=\chi 2=6264.297$, $\mathrm{df}=1081, \mathrm{p}<0.05)$ that rejected the null hypothesis. The data were not homogenous and indicated the correlation presence among variables and confirmed the suitability of these data for factor analysis. These measures fulfilled the assumptions of factor analysis such as sampling adequacy and homogeneous variance (Table 1).

Table 1: Results of KMO Measure of Sampling Adequacy and Bartlett's Test

\begin{tabular}{lrr}
\hline \hline & & Value \\
\hline \hline KMO Sampling Adequacy Measure. & & .848 \\
Bartlett's Test of Sphericity & $\chi^{2}$ & 6264.297 \\
& $D f$ & 1081 \\
& Sig. & .000 \\
\hline \hline
\end{tabular}

Principal Component Analysis (PCA) with varimax rotation was conducted to ascertain the appropriate number of components (factors) and grouping of statements in each of these components as it pertained to postgraduate students in this study. Varimax is the most 
commonly used rotation in PCA as it maximizes the variance of component or factor loading (Tabachnick and Fidell 2007; Field 2009). The initial analysis indicated 11 factors with eigenvalues more than one (1.0). According to Leech, Barrett, and Morgan (2005), the eigenvalue criterion is common for identification of the factor to be useful. These factors accounted for 65.7 percent of the cumulative variance as shown in Table 2. This initial exercise extracted a large number of factors as more factors result in a greater percentage of the total variance explained (Tabachnick and Fidell 2007; Field 2009). However, the retention of these large number of factors might affect the basic aim of factor analysis because it was a multivariate reduction technique.

Table 2: Initial Eigenvalues and Loadings for Original PCA Solution

\begin{tabular}{c|r|r|r|r|r|r}
\hline \multicolumn{7}{|c}{ Total Variance Explained } \\
\hline \multirow{2}{*}{ Component } & \multicolumn{7}{|c|}{ Initial Eigenvalues } & \multicolumn{1}{c}{ Extraction Sums of Squared Loadings } \\
\cline { 2 - 7 } & \multicolumn{1}{|c|}{ Total } & \% of Variance & Cumulative \% & \multicolumn{1}{c}{ Total } & \% of Variance & Cumulative \% \\
\hline 1 & 11.482 & 24.431 & 24.431 & 11.482 & 24.431 & 24.431 \\
2 & 4.944 & 10.519 & 34.950 & 4.944 & 10.519 & 34.950 \\
3 & 2.683 & 5.709 & 40.659 & 2.683 & 5.709 & 40.659 \\
4 & 2.311 & 4.916 & 45.575 & 2.311 & 4.916 & 45.575 \\
5 & 1.784 & 3.795 & 49.370 & 1.784 & 3.795 & 49.370 \\
6 & 1.583 & 3.368 & 52.738 & 1.583 & 3.368 & 52.738 \\
7 & 1.393 & 2.963 & 55.701 & 1.393 & 2.963 & 55.701 \\
8 & 1.336 & 2.843 & 58.544 & 1.336 & 2.843 & 58.544 \\
9 & 1.237 & 2.633 & 61.177 & 1.237 & 2.633 & 61.177 \\
10 & 1.084 & 2.306 & 63.482 & 1.084 & 2.306 & 63.482 \\
11 & 1.047 & 2.227 & 65.709 & 1.047 & 2.227 & 65.709 \\
\hline
\end{tabular}

Extraction Method: Principal Component Analysis.

Having an appropriate number of factors was identified using a scree plot criterion, that is to say, retaining all factors within the sharp descent before eigenvalues level-off or exclude factors that start after the plot's elbow or change slope (Johnson 1998; Rencher 1998; Tabachnick and Fidell 2007; Field 2009). Six factors were indicated in the scree plot (see Figure 1) as it clearly showed that plot elbow leveled off after factor six. While settling on a six-factor solution for underlying structure of ISAS for this study, the researcher not only took into account the examination of the eigenvalues, scree plot, and rotated component matrix, but also the results of Erfanmanesh, Abrizah, and Karim (2012) which indicated a six-factor solution.

A second PCA with varimax rotation was undertaken where variables (statements or items) were forced into six factors. Each factor in this six-factor solution obtained eigenvalues greater than 1.0. These six-factors combined together accounted for 52.7 percent of the total variance explained in the information seeking anxiety construct developed by this study (Table 3). The factor one (F1) accounted for 24.43 percent of the total variance explained with eigenvalue 11.82, factor two (F2) explained 10.51 percent of the total variance (eigenvalue $=4.94$ ) and factor three $(F 3)$ accounted for 5.70 percent of the total variance with eigenvalue 2.68. Factor four, five, and six (F4, F5, F6) accounted for 4.91 percent, 3.79 percent, and 3.36 percent of variance with eigenvalues $2.31,1.78$ and 1.58 respectively. 


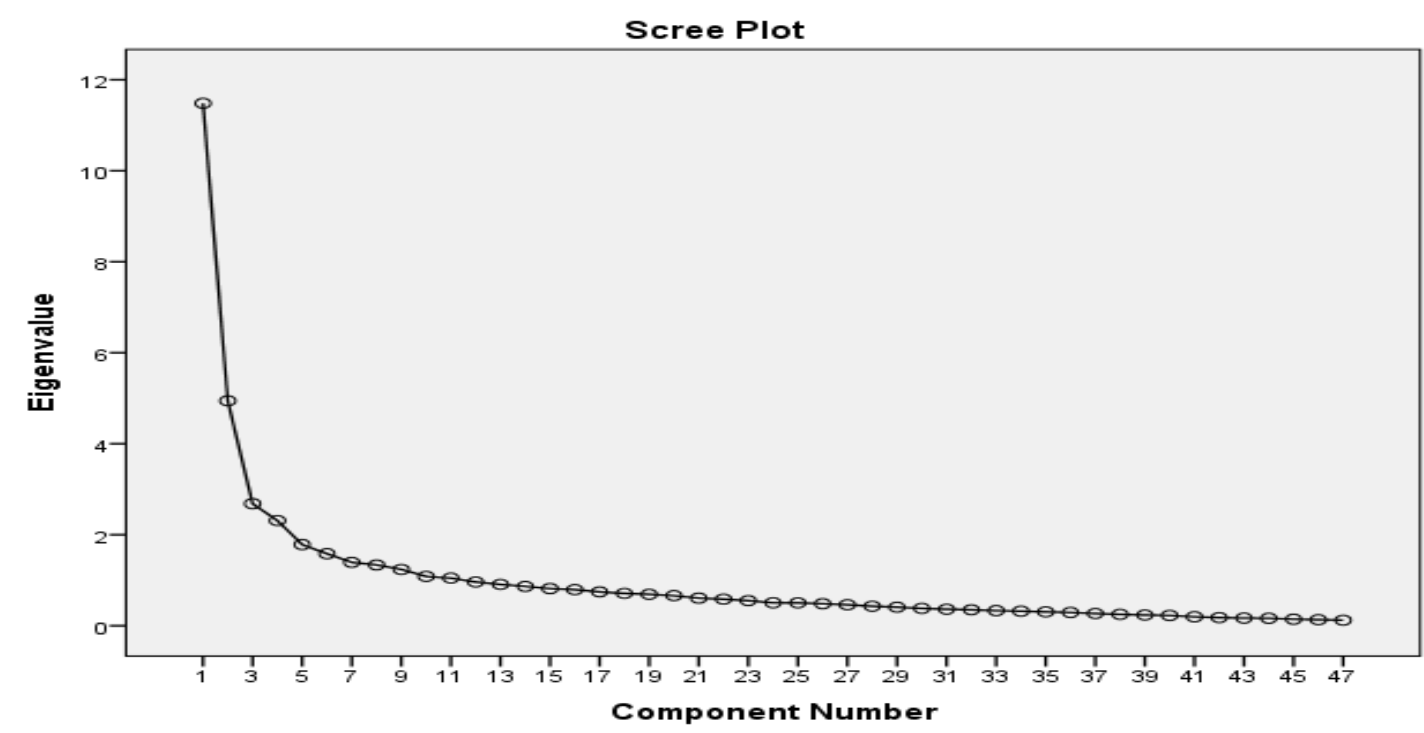

Figure 1: Initial Scree Plot for Original PCA Solution

Table 3: Initial Eigenvalues and Loadings for Six Component Solution

\begin{tabular}{c|r|r|r|r|r|r}
\hline \multicolumn{7}{|c}{ Total Variance Explained } \\
\hline \multirow{3}{*}{ Component } & \multicolumn{5}{|c|}{ Initial Eigenvalues } & \multicolumn{1}{c}{ Extraction Sums of Squared Loadings } \\
\cline { 2 - 7 } & \multicolumn{1}{|c}{ Total } & \% of Variance & Cumulative \% & \multicolumn{1}{c}{ Total } & \% of Variance & Cumulative \% \\
\hline 1 & 11.482 & 24.431 & 24.431 & 11.482 & 24.431 & 24.431 \\
2 & 4.944 & 10.519 & 34.950 & 4.944 & 10.519 & 34.950 \\
3 & 2.683 & 5.709 & 40.659 & 2.683 & 5.709 & 40.659 \\
4 & 2.311 & 4.916 & 45.575 & 2.311 & 4.916 & 45.575 \\
5 & 1.784 & 3.795 & 49.370 & 1.784 & 3.795 & 49.370 \\
6 & 1.583 & 3.368 & 52.738 & 1.583 & 3.368 & 52.738 \\
\hline
\end{tabular}

Extraction Method: Principal Component Analysis.

The researchers examined rotated components matrix for statements that cross-loaded on multiple factors and for statements that did not fit the underlying theory of the ISAS. The researchers did not allow any statement to cross-load on two separate factors in ultimate factor solution. If a statement cross-loaded, the researcher made a decision as to which component to allow that statement to load on based on its loading strength, underlying theory, and researcher's own judgment. Once the factors had been decided, they needed to be assigned appropriate names. The factor names were established based upon an examination of the specific statement loadings on each factor as well as existing research in the proposed area.

Sixteen statements were loaded on to factor one (F1) with rotated factor loadings ranging from .411 to .699 . Out of those sixteen statements, three were cross-loaded on to other factors. A total of thirteen (13) statements were retained with the same loading range as mentioned above (Table 4). This factor was labeled as "Resource Anxiety". Another sixteen statements were loaded on to factor two (F2) with loadings ranging from .406 to .704, with five items cross-loaded on to other factors. Eleven of these statements were retained in factor two (F2) having the same loading range and was tagged as "ICT Anxiety" (Table 5). The third factor (F3) consisted of thirteen statements of which two statements cross 
Naveed, M.A. \& Ameen, $K$.

loaded on to other factors. Nine of these statements were retained in this factor that exhibited factor loading ranging from .604 to .772 (Table 6) and it was named as "Library Anxiety".

Eight statements were loaded on to factor four (F4) with three statements cross-loaded on to other components. Only five of these statements were retained with rotated loadings that ranged from .540 to .705 (Table 7). This factor was labeled as "Search Anxiety". The fifth factor (F5) comprised of six items with factor loadings ranging from .384 to .629. Only one statement (S43) cross-loaded on to factor two (F2). This statement was already retained in factor two. It was, therefore, excluded from factor five (F5) which now consisted of five items (Table 8) and was named as "Mechanical Anxiety". Lastly, the factor six (F6) consisted of four statements with rotated factor loadings that ranged from .548 to .646 (Table 9). This factor retained all the items and was tagged as "Thematic Anxiety".

Table 4: Factor Loadings for "Resource Anxiety"

\begin{tabular}{|c|c|c|}
\hline No & Statement & Loading \\
\hline 1 & $\begin{array}{l}\text { S41("I feel anxious when I know information resources, but I don't have access } \\
\text { to them") }\end{array}$ & .699 \\
\hline 2 & $\begin{array}{l}\text { S12("Making judgment of the relevance of the retrieved information resources } \\
\text { make me anxious") }\end{array}$ & .635 \\
\hline 3 & $\begin{array}{l}\text { S23("I feel anxious when I find too many unfamiliar information resources } \\
\text { during information seeking process") }\end{array}$ & .601 \\
\hline 4 & $\begin{array}{l}\text { S20("Making judgment of the quality of the retrieved information resources } \\
\text { make me anxious") }\end{array}$ & .592 \\
\hline 5 & $\begin{array}{l}S 7 \text { ("I feel anxious when the quality of retrieved information resources are } \\
\text { unreliable") }\end{array}$ & .575 \\
\hline 6 & $\begin{array}{l}\text { S6("Unfamiliarity with information resources make me anxious during } \\
\text { information seeking process") }\end{array}$ & .523 \\
\hline 7 & $\begin{array}{l}\text { S4("I feel anxious when resources found during information seeking process } \\
\text { are irrelevant") }\end{array}$ & .511 \\
\hline 8 & $\begin{array}{l}\text { S27("I feel anxious when what is retrieved during information seeking process } \\
\text { is not up-to-date") }\end{array}$ & .499 \\
\hline 9 & $\begin{array}{l}\text { "S15(“When seeking for information resources, I usually experience negative } \\
\text { feelings like anxiety and frustration") }\end{array}$ & .485 \\
\hline 10 & $\begin{array}{l}\text { S34("I feel frustrated when information resources that I found are not easy to } \\
\text { use") }\end{array}$ & .480 \\
\hline 11 & $\begin{array}{l}\text { "S39(“I feel anxious when special skills are required to access information } \\
\text { resources") }\end{array}$ & .478 \\
\hline 12 & $\begin{array}{l}\text { S42 ("Restricted access to required full text resources make me anxious when I } \\
\text { seek for information") }\end{array}$ & .422 \\
\hline 13 & $\begin{array}{l}\text { S9("Finding poor quality information resources during information seeking } \\
\text { process make me frustrated") }\end{array}$ & .411 \\
\hline
\end{tabular}

"Items removed from the factor during reliability analysis 
Table 5: Factor Loadings for "ICT Anxiety"

\begin{tabular}{|c|c|c|}
\hline No & Statement & Loading \\
\hline 1 & $\begin{array}{l}\text { S44("I feel anxious when I cannot find necessary information } \\
\text { resources on the Internet") }\end{array}$ & .704 \\
\hline 2 & $\begin{array}{l}\text { "S17(“When seeking information, I feel uncomfortable using } \\
\text { electronic resources") }\end{array}$ & .649 \\
\hline 3 & $\begin{array}{l}\text { S25(“I feel anxious when seeking information from the library's } \\
\text { website”) }\end{array}$ & .620 \\
\hline 4 & $\begin{array}{l}\text { S46("When I use library's Online Public Access Catalogue for seeking } \\
\text { information, I feel frustrated") }\end{array}$ & .615 \\
\hline 5 & $\begin{array}{l}\text { S18("I do not feel comfortable using online resources when seeking } \\
\text { information resources") }\end{array}$ & .596 \\
\hline 6 & $\begin{array}{l}\text { "S37("Computers do not play an important role in my information } \\
\text { seeking process") }\end{array}$ & .550 \\
\hline 7 & $\begin{array}{l}\text { S45("I feel overwhelmed when I use the Internet for seeking } \\
\text { information resources") }\end{array}$ & .507 \\
\hline 8 & $\begin{array}{l}\text { S43("My Internet skills are not adequate for success in information } \\
\text { seeking part of my research") }\end{array}$ & .488 \\
\hline 9 & $\begin{array}{l}\text { S38("I feel anxious when different computer technologies are } \\
\text { required to retrieve the desire information resources") }\end{array}$ & .485 \\
\hline 10 & $\begin{array}{l}\text { S13(“I feel frustrated when I use computers for seeking information } \\
\text { resources") }\end{array}$ & .481 \\
\hline 11 & $\begin{array}{l}\text { S8("Unknown computer errors make me feel uneasy during the } \\
\text { information seeking process") }\end{array}$ & .406 \\
\hline
\end{tabular}

*Items removed from the factor during reliability analysis

Table 6: Factor Loadings for "Library Anxiety"

\begin{tabular}{|c|c|c|}
\hline No & Statement & Loading \\
\hline 1 & $\begin{array}{l}\text { S10("When seeking information resources in the university library, I feel } \\
\text { anxious because of the library's furniture") }\end{array}$ & .772 \\
\hline 2 & $\begin{array}{l}\text { "S32("I feel uncomfortable asking for help from the library staff when } \\
\text { seeking for information resources in the library") }\end{array}$ & .736 \\
\hline 3 & $\begin{array}{l}\text { "S40("I am not comfortable using library services for seeking information } \\
\text { resources") }\end{array}$ & .679 \\
\hline 4 & $\begin{array}{l}\text { S22("When seeking information resources in the university library, I feel } \\
\text { anxious because of the library's policies and procedures") }\end{array}$ & .670 \\
\hline 5 & $\begin{array}{l}\text { *S24 ("The university library does not offer enough information services for } \\
\text { postgraduate students") }\end{array}$ & .670 \\
\hline 6 & $\begin{array}{l}\text { S26("Inadequate library lighting make me feel uneasy when using the } \\
\text { library for seeking information resources") }\end{array}$ & .654 \\
\hline 7 & $\begin{array}{l}\text { S33(“My previous negative experiences affect my feelings negatively when I } \\
\text { use the university library for seeking information") }\end{array}$ & .615 \\
\hline 8 & $\begin{array}{l}\text { S36("The temperature in the university library is uncomfortable that I } \\
\text { cannot get my information seeking done") }\end{array}$ & .604 \\
\hline 9 & $\begin{array}{l}\text { S14("The librarian and library staff don't have time to help me when I } \\
\text { seeking information resources") }\end{array}$ & .503 \\
\hline
\end{tabular}


Table 7: Factor Loadings "Search Anxiety"

\begin{tabular}{clc}
\hline \hline No & \multicolumn{1}{c}{ Statement } & Loading \\
\hline \hline 1 & S29(“I feel anxious when I need information related to my research”) & .705 \\
2 & $\begin{array}{l}\text { S16("I am embarrassed that I do not know how to find information } \\
\text { resources") }\end{array}$ & .619 \\
3 & $\begin{array}{l}\text { S21(“I am worried about not being able to find the necessary information } \\
\text { during the information seeking process") }\end{array}$ & .554 \\
4 & $\begin{array}{l}\text { S11(“I am not sure how to start searching information resources”) } \\
5\end{array} \quad \begin{array}{l}\text { S35(“I feel anxious from the initial to the final stage of the information } \\
\text { seeking process") }\end{array}$ & .541 \\
\hline \hline
\end{tabular}

Table 8: Factor Loadings for "Mechanical Anxiety"

\begin{tabular}{clc}
\hline \hline No & \multicolumn{1}{c}{ Statement } & Loading \\
\hline \hline 1 & $\begin{array}{l}\text { S28(“I feel fear of making mistakes that cause system malfunction during } \\
\text { information seeking process") }\end{array}$ & .629 \\
2 & $\begin{array}{l}\text { S31("Rapid changes in familiar hardware and software make me anxious } \\
\text { when seeking information resources”) }\end{array}$ & .524 \\
3 & $\begin{array}{l}\text { S30(“I feel fear of damaging computers or other machines during } \\
\text { information seeking process") }\end{array}$ & .509 \\
4 & $\begin{array}{l}\text { S3(“Mechanical issues during information seeking process make me } \\
\text { anxious”) }\end{array}$ & .425 \\
5 & $\begin{array}{l}\text { S47(“I feel anxious when special equipment are required to access } \\
\text { information resources") }\end{array}$ & .384 \\
\hline \hline
\end{tabular}

Table 9: Factor Loadings for "Thematic Anxiety"

\begin{tabular}{clc}
\hline \hline $\mathrm{N}$ & \multicolumn{1}{c}{ Statement } & Loading \\
\hline \hline 1 & $\begin{array}{l}\text { S2("Selecting a general topic is a difficult part of the information seeking } \\
\text { process") }\end{array}$ & .646 \\
2 & S19(“Gathering information related to my specific topic make me anxious”) & .636 \\
3 & S1(“I feel anxious when selecting a general topic for my research”) & .635 \\
4 & $\begin{array}{l}\text { S5(“Exploring information on a general topic for finding a focus make me } \\
\text { anxious") }\end{array}$ & .548 \\
\hline \hline
\end{tabular}

\section{Reliability Analysis}

Cronbach's (1951) internal reliability coefficient alpha was used to determine the internal consistency of the overall ISAS and its sub-dimensions because it is an accepted and most commonly used measure of internal consistency and reliability (Gliner and Morgan 2000; Erfanmanesh, Abrizah and Karim 2012). This measure had successfully been used to estimate the internal consistency and reliability by many researchers (Anwar, Al-Kandari, and Al-Qallaf 2004; Anwar et al. 2012; Bowers 2010; Erfanmanesh, Abrizah and Karim 
2012). The value of reliability coefficient (CA) varies between zero (0) and one (1). A value closer to one indicates higher reliability whereas a value closer to zero indicates lower reliability of the instrument (Field, 2009; Erfanmanesh, Abrizah and Karim 2012).

The internal reliability coefficient (CA) was computed for overall Information Seeking Anxiety Scale (ISAS) and each of the six sub-scales. The first factor scored an alpha of 7.00. Although it was an acceptable value, it was decided to re-examine its internal reliability by dropping a statement (Table 10). Two statements (S15 and S39) were dropped which raised the alpha coefficient from 7.00 to 834 . Therefore, only eleven statements were retained in factor (F1) "Resource Anxiety". The second factor (F2) had an alpha of .691. By inspecting Table 11, it was found that dropping two items (S17 and S37) would raise the alpha value from .691 to .771. Therefore, these two statements were deleted from the factor "ICT Anxiety". Thus, the number of valid and reliable statements decreased to nine.

Table 10: Internal Reliability Analysis for "Resource Anxiety"

\begin{tabular}{ccc}
\hline \hline Number & Scale Item & $\begin{array}{c}\text { Cronbach's alpha } \\
\text { if item deleted }\end{array}$ \\
\hline \hline 1 & S41 & .713 \\
3 & S12 & .791 \\
4 & S23 & .699 \\
5 & S20 & .692 \\
6 & S7 & .721 \\
7 & S6 & .689 \\
8 & S4 & .711 \\
9 & S27 & .669 \\
10 & $*$ S15 & .811 \\
11 & S34 & .680 \\
12 & *S39 & .798 \\
13 & S42 & .655 \\
\hline \hline
\end{tabular}

*Items removed from the first factor

Factor three (F3) scored an alpha coefficient of .559 which was acceptable but with a low level of internal consistency. Further analysis indicated that if three items (S32, S40, and S24) were dropped from this factor, it would increase the alpha coefficient to .772 (Table 12). It was decided to drop these three statements from the factor (F3) labeled as "Library Anxiety". The alpha coefficients for the factors four, five, and six were .867, .821, and .872 respectively indicating an adequate internal consistency. Also, inspection of Table 13, 14, and 15 revealed that deletion of any item from these sub-scales would not significantly increase their reliability coefficients. It was, therefore, decided to not to make any modifications in or deletions from these loadings. 
Naveed, M.A. \& Ameen, $K$.

Table 11: Internal Reliability Analysis for "ICT Anxiety"

\begin{tabular}{ccc}
\hline Number & Scale Item & $\begin{array}{c}\text { Cronbach's alpha } \\
\text { if item deleted }\end{array}$ \\
\hline \hline 1 & S44 & .691 \\
2 & ${ }^{*} \mathrm{~S} 17$ & .741 \\
3 & $\mathrm{~S} 25$ & .679 \\
4 & $\mathrm{~S} 46$ & .689 \\
5 & $\mathrm{~S} 18$ & .672 \\
6 & ${ }^{*} \mathrm{~S} 37$ & .729 \\
7 & $\mathrm{~S} 45$ & .611 \\
8 & $\mathrm{~S} 43$ & .659 \\
9 & $\mathrm{~S} 38$ & .685 \\
10 & $\mathrm{~S} 13$ & .679 \\
11 & $\mathrm{~S} 8$ & .673 \\
\hline \hline
\end{tabular}

*Items removed from the second factor

Table 12: Internal Reliability Analysis for "Library Anxiety"

\begin{tabular}{ccc}
\hline \hline Number & Scale Item & $\begin{array}{c}\text { Cronbach's alpha } \\
\text { if item deleted }\end{array}$ \\
\hline \hline 1 & $\mathrm{~S} 10$ & .635 \\
2 & ${ }^{*} \mathrm{~S} 32$ & .721 \\
3 & ${ }^{*} \mathrm{~S} 40$ & .699 \\
4 & $\mathrm{~S} 22$ & .592 \\
5 & ${ }^{*} \mathrm{~S} 24$ & .687 \\
6 & $\mathrm{~S} 26$ & .623 \\
7 & $\mathrm{~S} 33$ & .611 \\
8 & $\mathrm{~S} 14$ & .599 \\
9 & $\mathrm{~S} 36$ & .585 \\
\hline \hline
\end{tabular}

* Items removed from the third factor

Table 13: Internal Reliability Analysis for "Search Anxiety"

\begin{tabular}{ccc}
\hline \hline Number & Scale Item & $\begin{array}{c}\text { Cronbach's alpha } \\
\text { if item deleted }\end{array}$ \\
\hline \hline 1 & S29 & .701 \\
2 & S16 & .735 \\
3 & S21 & .801 \\
4 & S11 & .792 \\
5 & S35 & .775 \\
\hline \hline
\end{tabular}


A Cross-Cultural Evaluation of the Psychometric Properties of Information Seeking Anxiety Scale

Table 14: Internal Reliability Analysis for "Mechanical Anxiety"

\begin{tabular}{ccc}
\hline Number & Scale Item & $\begin{array}{c}\text { Cronbach's alpha } \\
\text { if item deleted }\end{array}$ \\
\hline \hline 1 & S28 & .799 \\
2 & S31 & .753 \\
3 & S30 & .709 \\
4 & S3 & .789 \\
5 & S47 & .757 \\
\hline \hline
\end{tabular}

Table 15: Internal reliability analysis for "Thematic Anxiety"

\begin{tabular}{ccc}
\hline Number & Scale Item & $\begin{array}{c}\text { Cronbach's alpha } \\
\text { if item deleted }\end{array}$ \\
\hline \hline 1 & S2 & .851 \\
2 & S19 & .823 \\
3 & S1 & .801 \\
4 & S5 & .837 \\
\hline \hline
\end{tabular}

Dropping seven statements from different sub-dimensions of ISAS reduced the number of valid and reliable items to 40 from the original 47 items. The Cronbach alpha for the entire scale (40-items) was .906 indicating a high internal consistency of the overall ISAS. Table 16 presents the internal consistency for each of the six sub-scales along with overall ISAS.

Table 16: Internal Reliability for Overall ISAS and Sub-scales

\begin{tabular}{clcc}
\hline Number & Sub-scales & $\begin{array}{c}\text { Number of } \\
\text { statements }\end{array}$ & $\begin{array}{c}\text { Cronbach's } \\
\text { alpha }\end{array}$ \\
\hline \hline 1 & Resource Anxiety & 11 & .834 \\
2 & ICT Anxiety & 9 & .771 \\
3 & Library Anxiety & 6 & .772 \\
4 & Search Anxiety & 5 & .867 \\
5 & Mechanical Anxiety & 5 & .821 \\
6 & Thematic Anxiety & 4 & .872 \\
\hline \hline Total & Information Seeking Anxiety Scale & 40 & .906 \\
\hline \hline
\end{tabular}

\section{DISCUSSIONS AND CONCLUSIONS}

The intent of current study was to investigate the psychometric properties of information seeking anxiety scale, developed by Erfanmanesh, Abrizah, and Karim (2012), among postgraduate students at a Pakistani university. Of the 47 statements which were utilized to assess the phenomenon of information seeking anxiety, only 40 statements were loaded on six (6) interpretable components. The results of the exploratory principal components analysis (PCA) using varimax rotation yielded six-factor solutions to ISAS (Table 16). The 
loading strength of each statement ranged from .411 to .772. Each factor in this six-factor solution obtained eigenvalues greater than one (1). The six-factors were tagged as follows: (1) Resource Anxiety (11 statements, $\alpha=.834$ ); (2) ICT Anxiety (9 statements, $\alpha=.771$ ); (3) Library Anxiety (6statemnets, $\alpha=.772$ ); (4) Search Anxiety (5 statements, $\alpha=.867$ ); (5) Mechanical Anxiety (5 statements, $\alpha=.821$ ); and, (6) Thematic Anxiety (4 statements, $\alpha$ $=.872$ ). Subsequently, each factor was examined for internal reliability. The results indicated that each factor has met the suggested criterion of 0.70 by Nunnally and Bernstein (1994). In addition, the internal reliability for overall ISAS (40 statements) were also examined and was found to have a Cronbach's alpha value of 0.90 . The high value of alpha coefficient also met the above mentioned criteria. Moreover, the values of internal reliability coefficient $(\alpha)$ for each statement varied from .585 to .851 which were acceptable and quite reasonable (Field 2009). However, it is interesting to note that all the sub-scales and overall scale is internally reliable.

The results of the proposed study were consistent with the original study insofar as the total number of factors produced. The pioneering psychometric effort, by Erfanmanesh, Abrizah and Karim (2012) while developing and validating ISAS, resulted in six-factor solution which collectively explained about 35 percent of the total variation in information seeking anxiety construct. The current study also revealed a six-factor solution to ISAS and these factors collaboratively accounted for 52.7 percent of the total variance explained in the information seeking anxiety construct which is 17 percent more than that of the findings of original study. Although the identified six factors were consistent with those of Erfanmanesh, Abrizah, and Karim (2012) but these factors slightly differed with regard to the loading statements on each factor. Consequently, the assigned labels were also different from the earlier labels assigned by the original authors. Furthermore, the results regarding internal reliability are also consistent with the previous study insofar as the estimates of internal reliability are concerned. Both studies revealed the internal reliability estimate for the overall scale to be at 0.90 . The internal reliability for the overall ISAS as well as for each of the six dimensions in both studies was also found to have satisfied the criterion of 0.70 (Nunnally and Bernstein 1994).

In addition, the results of the present study support the findings of Erfanmanesh, Abrizah and Karim (2012) in that the sub-dimension 'Resource Anxiety' explained the highest proportions of the total variance in scores of information seeking anxiety. In their study, the sub-scale 'barriers associated with information resources' explained 15.67 percent of the total variance whereas in the present study the 'Resource Anxiety' explained 24.43 percent of the total variance in information seeking anxiety. Hence, this study also provided incremental validity to Erfanmanesh, Abrizah and Karim's (2012) study in that the same sub-dimension turns out to be the best main predictor of information seeking anxiety. Moreover, the sub-dimension 'Thematic Anxiety' explained the lowest proportions of the total variances as the 'barriers associated with topic identification' explained 2.66 percent of the total variance while in the current study it explained 3.36 percent of the total variance. It means that the topic identification barriers are the lowest predictor of information seeking anxiety as found in both studies.

The results of the current study demonstrated the psychometric soundness and stability of ISAS when tested among postgraduate students at a university in Punjab, Lahore. This study is thereby lending cross-cultural evidence of the psychometric properties of the Information Seeking Anxiety Scale developed by Erfanmanesh, Abrizah and Karim (2012). Although this study provided an incremental validity to the information seeking anxiety construct, it is too early to generalize these results to all postgraduate students in other 
universities in Pakistan. As such, more psychometric evaluations are needed before concluding that ISAS is a psychometrically sound and stable when applied in a crosscultural environment. The resultant 40 -item ISAS validated by this study further needs to be tested with other postgraduate students recruited from other Pakistani institutions of higher learning. Until and unless the resultant 40-item ISAS is validated with other postgraduate students, the results of this study would remain tentative and empirically inconclusive. It is, therefore, further validation studies of ISAS are recommended to determine its construct validity in different academic settings. These studies should undertake both confirmatory and exploratory factor analysis to examine the construct validity in various other groups having different cultures and locales. In particular, the six factor solution should be retested for their validity and reliability.

\section{ACKNOWLEDGEMENT}

This research received no specific grant from any funding agency in the public, commercial, or not-for profit sectors.

\section{REFERENCES}

Anwar, M. A., Al-Kandari, N. M., and Al-Qallaf, C. L. 2004. Use of Bostick's Library Anxiety Scale on undergraduate biological sciences students of Kuwait University. Library \& Information Science Research, Vol. 26, no. 2: 266-283.

Anwar, M. A., Al-Qallaf, C. L., Al-Kandari, N. M., and Al-Ansari, H. A. 2012. AQAK: A library anxiety scale for undergraduate students. Journal of Librarianship and Information Science, Vol. 44, no. 1: 36-46.

Bostick, S. L. 1992. The Development and Validation of the Library Anxiety Scale. Doctoral dissertation. Wayne State University. 176p.

Bowers, S. L. 2010. Library anxiety of law students: A study utilizing the Multidimensional Library Anxiety Scale. PhD dissertation, University of Denver.

Erfanmanesh, M. A. 2011. Use of Multidimensional Library Anxiety Scale on education and psychology students in Iran. Library Philosophy \& Practice 1-10. Accessed December 27, 2012. Available at: http://www.webpages.uidaho.edu/ mbolin/erfanmanesh.pdf.

Erfanmanesh, M., Abrizah, A. and Karim, N. H. A. 2012. Development and validation of the Information Seeking Anxiety Scale. Malaysian Journal of Library \& Information Science, Vol. 17, no. 1: 21-39.

Erfanmanesh, M., Abrizah, A. and Karim, N. H. A. 2014a. Information seeking anxiety: concept, measurement and preliminary research. International Journal of Information Science \& Management, Vol. 12, no. 1: 47- 64.

Erfanmanesh, M., Abrizah, A., and Karim, N. H. A. 2014b. The prevalence and correlates of information seeking anxiety in postgraduate students. Malaysian Journal of Library \& Information Science, Vol. 19, no. 2: 69-82.

Field, A. 2009. Discovering statistics using SPSS. $3^{\text {rd }}$ ed. London: SAGE.

Gay, L. R., Mills, G. E. and Airasian, P. 2009. Educational research: Competencies for analysis and applications. ( $9^{\text {th }}$ ed.). New Jersey: Pearson.

Gliner, J. A., and Morgan, G. A. 2000. Research methods in applied settings: An integrated approach to design and analysis. Mahwah, NJ: Lawrence Erlbaum Associates.

Hatchard, D. B., and Toy, P. 1986. The psychological barriers between library users and library staff: An exploratory investigation. Australian Academic and Research Libraries, Vol. 17, no. 2: 63-69. 
Hutcheson, G. D. and Sofroniou, N. 1999. The multivariate social scientist: Introductory statistics using generalized linear models. London: Sage.

Jiao, Q. G. and Onwuegbuzie, A. J. 2001. Sources of library anxiety among international students: study of undergraduates at an urban university in the northeast. Urban Library Journal, Vol. 11, no. 1: 16-26.

Jiao, Q. G., and Onwuegbuzie, A. J. 1997. Antecedents of library anxiety. Library Quarterly, Vol. 67, no. 4: 372-389.

Jiao, Q. G., and Onwuegbuzie, A. J. 1998. Perfectionism and library anxiety among graduate students. Journal of Academic Librarianship, Vol. 24, no. 5: 365-372.

Jiao, Q. G., and Onwuegbuzie, A. J. 1999. Self-perception and library anxiety: An empirical study. Library Review, Vol. 48, no. 3: 140-147.

Jiao, Q. G., Onwuegbuzie, A. J., and Lichtenstein, A. A. 1996. Library anxiety: Characteristics of 'at-risk' students. Library and Information Science Research, Vol. 18, no. 2: 151163.

Johnson, D. E. 1998. Applied multivariate methods for data analysts. Pacific Grove: Duxbury Press.

Kaiser, H. F. 1981. A revised measure of sampling adequacy for factor-analytic data matrices. Educational and Psychological Measurement, Vol. 41, no. 2: 379-381.

Karim, N. H. A. and Ansari, N. 2010. A cross cultural evaluation of Bostick's Library Anxiety Scale: Investigating the scale's psychometric properties in a Malaysian university library environment. Malaysian Journal of Library \& Information Science, Vol. 15, no. 1: 115-134.

Kuhlthau, C. C. 1988. Developing a model of the library search process: Cognitive and affective aspects. Reference Quarterly, Vol. 28, no. 2: 232-242.

Kuhlthau, C. C. 1991. Inside the Search Process: Information seeking from the user's perspective. Journal of the American Society for Information Science, Vol. 42, no. 5: 361-371.

Leech, N., Barrett, K. C., and Morgan, G. 2005. SPSS for intermediate statistics: Use and interpretation. Mahwah, NJ: Erlbaum.

Mellon, C. A. 1986. Library anxiety: A grounded theory and its development. College \& Research Libraries, Vol. 47, no. 2: 160-165.

Naveed, M. A. 2016. Exploring information seeking anxiety among research students in Pakistan. Libri: International Journal of Libraries and Information Services, Vol. 66, no. 1: 73-82.

Naveed, M. A., and K. Ameen. 2016. Measuring levels of students' anxiety in information seeking tasks. Pakistan Journal of Information Management and Libraries, No. 17: 56 -68 .

Nunnally, J. C. and Bernstein, I. H. 1994. Psychometric theory (3rd ed.). New York: McGrawHill.

Onwuegbuzie, A. J. 1997. Writing a research proposal: The role of library anxiety, statistics anxiety, and composition anxiety. Library \& Information Science Research, Vol. 19, no. 1: 5-33.

Onwuegbuzie, A. J., and Jiao, Q. G. 1997. Academic library usage: A comparison of native and non-native English-speaking students. Australian Library Journal, Vol. 46, no. 3: 258-269.

Onwuegbuzie, A. J., and Jiao, Q. G. 2000. I'll go to the library later: The relationship between academic procrastination and library anxiety. College \& Research Libraries, Vol. 61, no. 1: 45-54.

Platt, J., and Platt, T. L. 2013. Library anxiety among undergraduates enrolled in a research methods in psychology course. Behavioral \& Social Sciences Librarian, Vol. 32, no. 4, 240-251. 
Rencher, A. C. 1998. Multivariate statistical inference and applications. New York: Wiley.

Shoham, S., and Mizrachi, D. 2004. Computer attitudes and library anxiety among undergraduates: A study of Israeli B. Ed. Students. The International Information \& Library Review, Vol. 36, no. 1: 29-38.

Swigon, M. 2011. Library anxiety among Polish students: Development and validation of the Polish Library Anxiety Scale. Library \& Information Science Research, Vol. 33, no. 2: 144-150.

Swope, M. J., and Katzer, J. 1972. Why do not they ask questions? Reference Quarterly, Vol. 12: $161-166$.

Tabachnick, B. G., and Fidell, L. S. 2007. Using multivariate statistics ( $5^{\text {th }}$ ed.). Boston: Pearson Education.

Van Kampen, D. J. 2004. Development and validation of the Multidimensional Library Anxiety Scale. College \& Research Libraries, Vol. 65, no. 1: 28-34. 